\title{
Comparative Evaluation of Tissue Protein Separations Applying One- Dimensional Gel Electrophoresis and Capillary Gel Electrophoresis
}

\author{
Ilona Olędzka ${ }^{1}, K_{\text {Kamil Włodarski }}{ }^{,}$Jolanta Paradziej-Łukowicz ${ }^{2}$ and Tomasz Bączek ${ }^{1, *}$ \\ ${ }^{I}$ Department of Pharmaceutical Chemistry, Medical University of Gdańsk, Hallera 107, 80-416 Gdańsk, Poland \\ ${ }^{2}$ Tri-City Central Animal Laboratory - Research and Service Centre, Medical University of Gdańsk, Gdańsk, Poland
}

\begin{abstract}
The objective of this study was to characterize and compare the water and salt soluble proteins from rat liver and muscle by using sodium dodecyl sulphate polyacrylamide gel electrophoresis (SDS-PAGE) and sodium dodecyl sulphate polymer-filled capillary gel electrophoresis (SDS-CGE). The evaluation and comparison of separations realized with the use of both techniques was done. It was found that although the main separation mechanism have similar in both cases. However, it was considered that, SDS-CGE seems to have a potential to be the alternative, efficient tool for the separation of tissue proteins based purely on their molecular weights.
\end{abstract}

Keywords: Sodium dodecyl sulphate polyacrylamide gel electrophoresis (SDS-PAGE), sodium dodecyl sulphate polymerfilled capillary gel electrophoresis (SDS-CGE), Rat tissue.

\section{INTRODUCTION}

The development of electrophoretic techniques makes it possible to detect the protein composition and diagnose corresponding pathologies. This is due to the fact that the diagnosis of pathological process is based not on monitoring of a single biomarker but on simultaneous analysis of hundreds of proteins or peptides and generating a unique combination of profiles [1]. This unique combination of protein biomarkers could constitute a sensitive tool for early detection of the disease.

In addition to the protein structure, the methods used in biomedical analysis, allow to explore their interaction, distribution, concentration changes, and modifications that occur in disease processes. This has contributed to a better understanding of the functioning of organism's and to meet potential biomarkers of diseases [2-5]. The use of proteins as endogenous biomarkers of early biological effects is for example particularly useful for the early diagnosis of cancer in people with high-risk groups and to monitor treatment efficacy and predicting tumor recurrence after surgery and also allows to determine early changes in people suffering from mental or neurodegenerative diseases. Interest in these indicators stems from the fact that some of these levels in body fluids increase long before the onset of clinically overt cancer [6-8]. For complex protein mixtures it is necessary to use analytical instruments, possessing a high capacity separation of chemical compounds.

Sodium dodecyl sulphate-polyacrylamide gel electrophoresis (SDS-PAGE) otherwise known as one-dimensional gel electrophoresis (1D-GE), is highly valued and well-

*Address correspondence to this author at the Department of Pharmaceutical Chemistry, Medical University of Gdańsk, Hallera 107, 80-416 Gdańsk, Poland; Tel: +48 58 3491633; E-mail: tbaczek@gumed.edu.pl known method for over 40 years. During this period, many of its varieties were developed, each of which had limited applications due to the diversity of biological material as well as different analytical goals posed by the scientists themselves. Nevertheless, SDS-PAGE is time-consuming, labor-intensive, marginalny quantitable and not readily amenable to automation. However, no doubt that gel electrophoresis using sodium dodecyl sulfate (SDS) allowing of proteins molecular weight-based separations, has been widely used $[9,10]$.

On the other hand, capillary gel electrophoresis (SDSCGE) provides a simple, fast and automated method for protein separation. CGE is characterized by high resolution $\left(10^{5}-10^{6}\right.$ theoretical plates), good precision and low consumption of reagents [11-16]. The analyzed particles were coated with SDS, which allows to obtain the same negative charge density on each of them. This allows the attraction of particles to the electrode with the same force, and on their separation affects only the weight. As the filling of the capillary buffer containing TRIS (trihydroksymetyloaminometan), phosphoric acid and $0.1 \% \operatorname{SDS}(\mathrm{pH} 8.6)$ is usually used.

The aim of this study was the separation of proteins from rats liver and muscle by sodium dodecyl sulphate polyacrylamide gel electrophoresis (SDS-PAGE) and capillary gel electrophoresis (SDS-CGE). In addition to the selection of appropriate conditions for separations, both methods were compared in technical terms and the assessment of protein profiles of two rat tissues was performed.

\section{MATERIALS AND METHODS}

\section{Reagents}

The protein molecular mass markers: Precision Plus Dual Color for SDS-PAGE experiments was obtained from (BioRad, Hercules, CA, USA), in turn SDS MW Size 
Standard for SDS-CGE experiments was obtained from (Beckman Coulter, Fullerton, CA, USA). Biochemical grade urea, SDS, $\beta$-mercaptoethanol, were purchased from BioRad (BioRad, Hercules, CA, USA). Highly pure water was obtained from Milli-Q water system (Millipore, Bradford, MA, USA).

\section{Apparatus}

The experiments were carried out on Mini-PROTEAN 3 Cell electrophoretic apparatus (Bio-Rad, Hercules, CA, USA) and P/ACE MDQ capillary electrophoresis system (Beckman Instruments, Fullerton, CA, USA), equipped with an UV detection system. The Polytron homogenization apparatus PT 2100 from Kinematica (Littau-Lucerne, Switzerland) for homogenization of rat tissue samples was also used.

\section{Animal Tissues Materials}

The material for the study (rat tissue) came from animals laboratory, intended for animal research. In Tri-City Central Animal Laboratory - Research and Service Centre, animals are tested in assessing the general condition, blood test for the presence of pathogens, and the section and pathological evaluation is systematically performed. The material for research was collected during routine operations performed by a veterinarian during the health checks of laboratory animals.

\section{Sample Preparation}

Extracted and frozen rat organs (muscle, liver) were divided into 1-2 $\mathrm{mm}$ pieces and then weighed about $0.025 \mathrm{~g}$ each. Samples were placed in Eppendorf tubes with $0.5 \mathrm{ml}$ of saline. Then samples were homogenized for $1 \mathrm{~min}$. The total protein content of the extracts was determined by the RCDC Protein Assay (BioRad, Hercules, CA, USA) and apparatus for measuring the absorbance Multiscan FC. To construct the calibration curve, the standard solutions of bovine serum albumin (BSA) have been prepared and used to determine the protein concentration in each tissue samples. Dependence of absorbance on concentration for standard solutions, after averaging two absorbance values for each of the concentrations, led to the linear function $y=a x+b$, where $y$ is the absorbance, and $x$ is the concentration expressed in $\mathrm{mg} / \mathrm{ml}$. The equation $(y=0.1115 x+0.0163)$ allowed the calculation of protein concentration in individual tissue samples. The measured values of protein concentration in liver and muscle samples were $10.025 \mathrm{mg} / \mathrm{ml}$ and 4.83 $\mathrm{mg} / \mathrm{ml}$, respectively. In order to prepare samples for further analysis, both in SDS-PAGE and in SDS-CGE, $25 \mu \mathrm{l}$ of supernatant was used. The final total protein concentration in analyzed samples was respectively $0.25 \mathrm{mg} / \mathrm{ml}$ for liver, and $0.12 \mathrm{mg} / \mathrm{ml}$ for muscle samples.

\section{SDS-PAGE}

Before analysis, samples were mixed with a buffer consisting of Tris- $\mathrm{HCl}(\mathrm{pH} 8.6), 2 \%$ SDS, 40\% glycerol and $\beta$-mercaptoethanol, and $0.02 \%$ bromophenol blue. The buffer was mixed with the same volume of test protein sample and the mixture was incubated in a water bath at 100 ${ }^{\circ} \mathrm{C}$ for $3 \mathrm{~min}$ and centrifuged at $14000 \mathrm{~g}$ for $10 \mathrm{~min}$. In the case of proteins being extremely difficult to dissolve, the urea can be added, which destroys hydrogen and hydrophobic bonds and prevents the formation of protein aggregates. Addition of glycerol increased the density of the sample and facilitated the application of the gel, while the bromophenol blue stained and allowed to observation of the separation occurring on the gel. Then, a volume of $25 \mu$ protein sample was introduced at the top of the gel and electrophoresis was conducted at constant $200 \mathrm{~V}$ for $1 \mathrm{~h}$. Separation was carried out on $3 \%$ thickener gel $(0.5 \mathrm{M}$ Tris $\mathrm{HCl}, \mathrm{pH} 6.8)$ and $15 \%$ separating gel (1.5 M Tris- $\mathrm{HCl}, \mathrm{pH}$ 8.8). The electrode buffer of $\mathrm{pH} 8.35$ contained $0.025 \mathrm{M}$ Tris, $0.192 \mathrm{M}$ glicine and $0.1 \%$ SDS.

Separated proteins were visualized. The most commonly used methods to staining are Coomassie Brilliant Blue (Coomassie Brilliant Blue G-250) and silver salts. Both consist of immersing the gel in the appropriate solutions. The first is less labor intensive and can detect $0.1 \mathrm{mg}$ of protein, while the other requires several stages of dyeing and controlling the entire process. However, it is much more sensitive, since silver ions by binding to the carboxyl groups and thiol already enable the detection of $0.5 \mathrm{ng}$ of protein. In this experiment, the gel were stained with $1 \%$ Coomasie Briliant Blue (CBB G-250) for $1 \mathrm{~h}$ according to the manufacturer's instructions and then destained with solution containing $10 \%$ ethanol and $10 \%$ acetic acid.

\section{SDS-CGE}

Protein samples $(25 \mu \mathrm{l})$ were dissolved in a buffer solution composed of $12 \mathrm{mM}$ Tris- $\mathrm{HCl}, 0.5 \% \mathrm{SDS}$ and 5 $\mathrm{mM}$ dithiotreitol (DTT). Then the samples were denaturized by heating at $100{ }^{\circ} \mathrm{C}$ for $3 \mathrm{~min}$ before sample injection. The gel buffer for SDS-CGE consisted of 5\% dextran in $0.1 \%$ SDS and $50 \mathrm{mM}$ Tris-borate with a proprietary positively charged polymer for dynamic coating to reduce electroosmotic flow was used.

The P/ACE MDQ - capillary electrophoresis instrument utilizing UV absorbance detection at $220 \mathrm{~nm}$ (Beckman Coulter, Fullerton, CA, USA) was employed for all protein separation. The system was fitted with $50 \mu \mathrm{m}$ i.d. uncoated silica capillary with $27 \mathrm{~cm}$ effective length (Beckman Coulter, Fullerton, CA, USA). Sample storage and cartridge temperature were maintained at $25^{\circ} \mathrm{C}$. Briefly, new capillary was pre-conditioned. The methodology was based on six-run cycles. This method served to clean the capillary and equilibrate them. Before each separation, capillary was rinsed with $0.1 \mathrm{~N} \mathrm{NaOH}$ for $3 \mathrm{~min}, 0.1 \mathrm{~N} \mathrm{HCl}$ for $1 \mathrm{~min}$, water for $1 \mathrm{~min}$, then gel separation buffer for $10 \mathrm{~min}$ in forward direction. All rinse pressures were 70 psi (4.8 bar). In addition, both ends of the capillary were placed twice in two different water vials to clean the viscous, residual gel buffer before sample injection. The sample was injected at the anode with reverse polarity using $5 \mathrm{kV}$ for 20-30 s, then both ends of the capillary were placed in water again to remove residual sample. The sample was separated at $15 \mathrm{kV}$ with reverse polarity and by applying 70 psi (4.8 bar) pressure at both ends of the capillary during the $30 \mathrm{~min}$ of separation time. A typical current of $27 \mathrm{~mA}$ was observed during separation.

According to literature data the protein concentration in the sample should be in the range from 0.2 to $2.0 \mathrm{mg} / \mathrm{ml}$. The relative concentration $(\mu \mathrm{g} / \mathrm{ml})$ of separated proteins was 
calculated with the use of an internal standard averaging three independent replicates. For the best results, the recommended protein concentration was $1 \mathrm{mg} / \mathrm{ml}$. If the protein concentration was too high, it may result in insufficient SDS binding, giving broad peaks and poor resolution. One the other hand, if the protein concentration was too low, a low signal will be observed. Protein peaks with an average concentration lower than $20 \mu \mathrm{g} / \mathrm{ml}$ were not considered, since their significance is close to the detection limit of the instrument.

\section{RESULTS AND DISCUSSION}

Polyacrylamide gel electrophoresis is a widely used method for determining the molecular weight of proteins in denaturing conditions. Experiments conducting with dyeing takes several hours and $0.1 \mu \mathrm{g}$ of protein stained Coomasie Briliant Blue gives a clear band. The polyacrylamide gel pore size can be controlled by choosing the appropriate concentration of polyacrylamide and metylenoacrylamide for polymerization process. In addition, polyacrylamide gels are chemically inert, hence they are versatile analytical tool.

The $15 \%$ gel allowed to obtain satisfactory separations of proteins in examined tissues samples. It was also possible visual assessment of the relative concentration of proteins in the tissue on the basis of color intensity.

A distinctive number of stained bands, in the case of the liver tissue confirmed that it is a tissue that has the high concentration of proteins in the body (Fig. 1A). Protein present in the liver sample were found in a wide range from
10 to $250 \mathrm{kD}$, but they were present in low concentrations, some even at the limit of detection.

In a sample of muscle tissue can be seen the darkest band located between 37 and 50kD (Fig. 2A). It can suspect that it is actin, whose molecular weight is $42 \mathrm{kD}$ and which together with myosin, is most abundant muscle protein. No presence of myosin on the gel could be due to the fact that it is a protein with an unusually large mass of approximately $470 \mathrm{kD}$. Its input into the gel and separation would be possible only with a much lower value of $\% \mathrm{C}$.

Fig. (3) shows a typical electropherograms from SDSCGE of separation The Protein Sizing Standard Test Mix contained seven proteins $(10 \mathrm{kD}, 20 \mathrm{kD}, 35 \mathrm{kD}, 50 \mathrm{kD}, 100$ $\mathrm{kD}, 150 \mathrm{kD}$ and $225 \mathrm{kD}$ ). All proteins were completely separated within $30 \mathrm{~min}$ using recommended method. Electropherograms obtained in SDS-based capillary gel electrophoresis also allowed to determine the molecular weight of the tissue proteins, hence similar information as SDS-PAGE could be found here, too. Determination of molecular weight of analytes was based on protein standards, whose time of reaching the detector in a capillary was presented on a separate electropherogram (Fig. 3). Migration time dependence of the molecular weight allowed the calibration curve preparation. On each of the electropherograms around $12 \mathrm{~min}$ there was a distinctive peak, which is the internal standard protein added to an each sample. It was a protein of low molecular weight of approximately $10 \mathrm{kD}$, after which follow the proteins analyzed in accordance with the growing masses. Experiments performed by SDS-
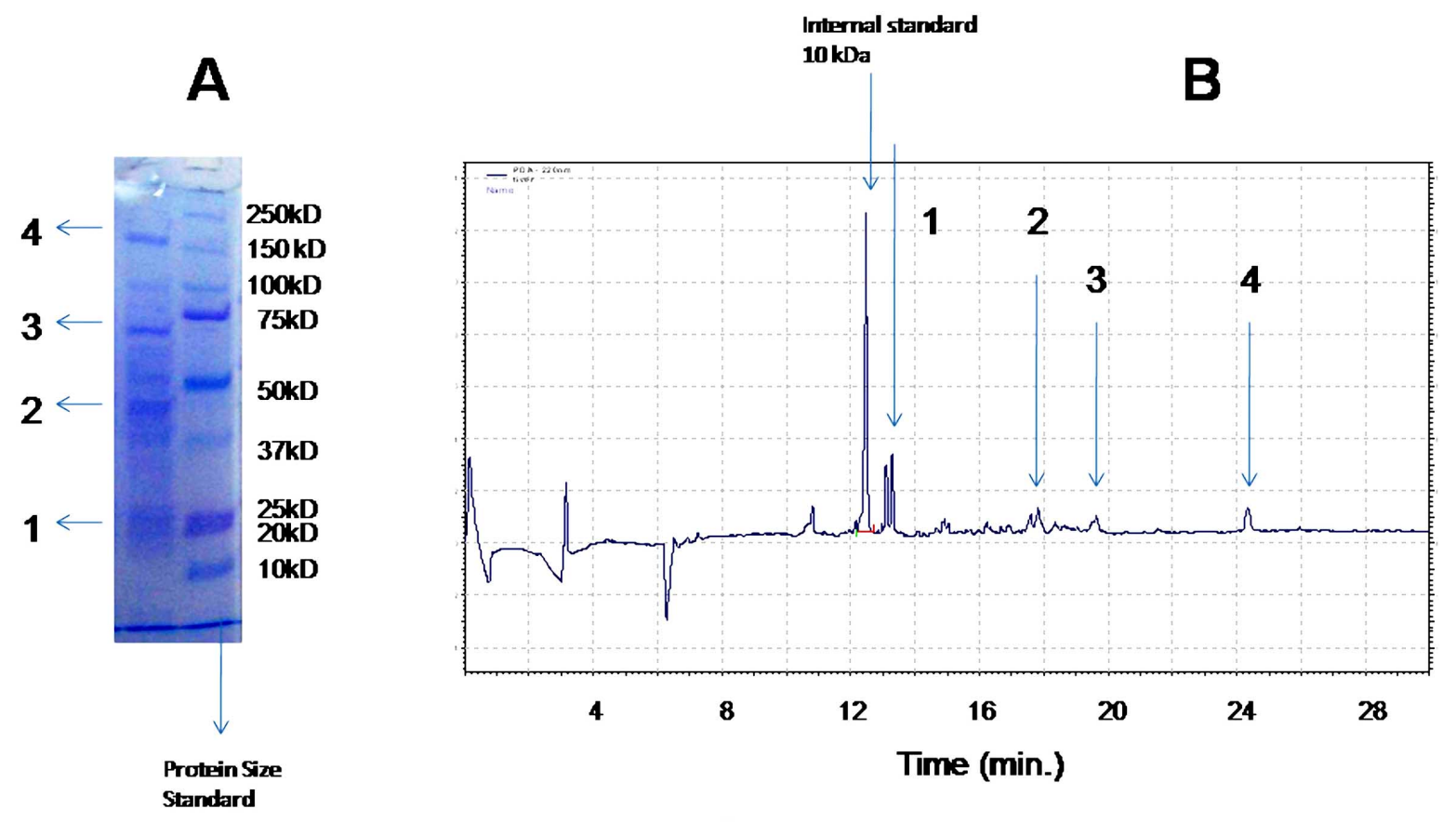

\section{1- Proteins $20-25$ kDa \\ 2-Proteins $50 \mathrm{kDa}$ \\ 3- Protein 75 kDa \\ 4- Protein 150 kDa}

Fig. (1). Separation of homogenates of rat liver obtained by SDS-PAGE (15\% separating gel, $200 \mathrm{~V}$ for $1 \mathrm{~h})$ (A) and obtained by SDS-CGE $(15 \mathrm{kV}, 70 \mathrm{psi} / \mathrm{s}, \mathrm{UV}$ at $220 \mathrm{~nm})(\mathbf{B})$. 

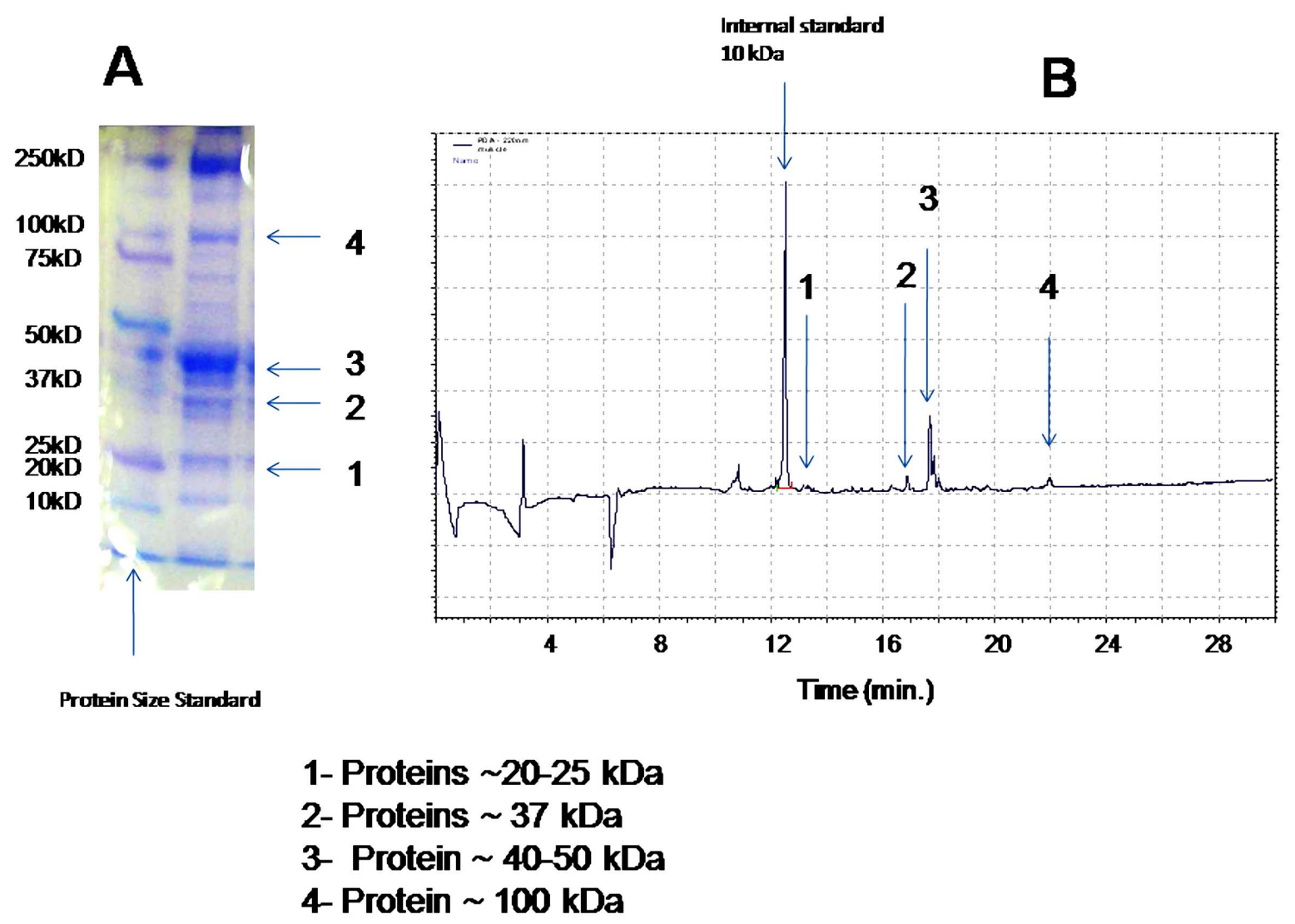

Fig. (2). Separation of rat muscle obtained by SDS-PAGE (15\% separating gel, $200 \mathrm{~V}$ for $1 \mathrm{~h})(\mathbf{A})$ and obtained by SDS-CGE (15 kV, 70 psi/s, UV at $220 \mathrm{~nm})($ B).

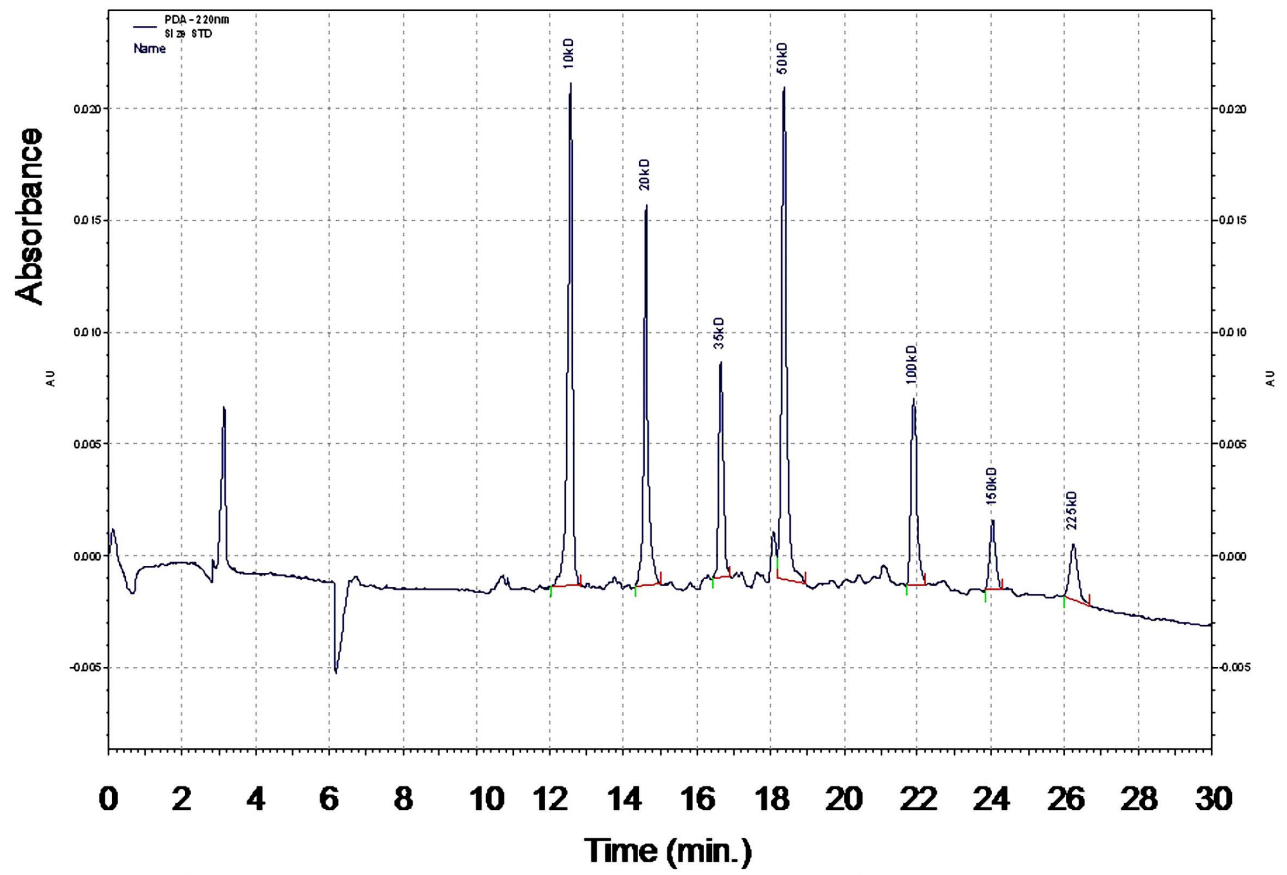

Fig. (3). Electropherogram obtained by SDS-CGE (15 kV, $70 \mathrm{psi} / \mathrm{s}$, UV at $220 \mathrm{~nm})$ of the Protein Sizing Standard Test Mix contains seven proteins $(10 \mathrm{kD}, 20 \mathrm{kD}, 35 \mathrm{kD}, 50 \mathrm{kD}, 100 \mathrm{kD}, 150 \mathrm{kD}$ and $225 \mathrm{kD})$.

CGE confirmed that liver tissue was rich in a variety of proteins with a wide range of molecular weights (Fig. 1B). Electropherograms of liver contained the most numerous peaks appearing between 12 and $25 \mathrm{~min}$, which can be attributed to the mass in the range from 10 to $225 \mathrm{kD}$ (similarly as in the case of SDS-PAGE). The presence of actin in muscle tissue was confirmed peak between 17 and 18 min corresponding to $42 \mathrm{kD}$ (Fig. 2B). 


\section{CONCLUSION}

Experiments presented in the paper represent a preliminary analysis to compare the information obtained by two electrophoretic methods, namely SDS-PAGE and SDSCGE. Both methods allowed to separate proteins and to determine their molecular weights, abolishing the effect of protein shape and charge on its migration. Evaluation of the intensity and size of stripes and spots in SDS-PAGE allowed the relative evaluation of protein concentration in the sample. However, knowledge of the rate of migration of particles in the SDS-CGE allows for an easier quantitative analysis based on a comparison of the area under the peak of the calibration curve. Single band on SDS-PAGE gel may be one protein, but also a mixture of proteins with similar molecular weight. Due to the limited resolution, SDS-PAGE is little effective for separation of molecules with very similar molecular weights. SDS-PAGE method also has advantages. It can be used not only to evaluate the particle mass and purity of the preparation but more often is used for the separation and purification of proteins. The bands containing the separated molecules can be cut from the gel, digested, and after receiving the pure product subject to further structural analysis. In other hand, SDS-CGE as a method for high efficiency was characterized by a higher resolution and allowed to separate the protein with even slightly different molecular weight. Samples for capillary methods were easy to prepare, and the separation took just a few minutes. In comparison, SDS-PAGE was a technique more laborious, time consuming, poorly automated and required great analytical skill.

\section{CONFLICTS OF INTEREST}

Declared none.

\section{ACKNOWLEDGMENTS}

The work was supported by the Polish State Committee for Scientific Research Project N N405 423839.

\section{REFERENCES}

[1] Baak, J.P.; Path, F.R.; Hermsen, M.A. Genomics and proteomics in cancer. Eur. J. Cancer, 2003, 39, 1199-1215.

[2] Karger, L.B.; Hancock, S.W.; Eds. Methods in Enzymology. High Resolution Separation and Analysis of Biological Macromolecules. Academic Press: San Diego, 1996, vol. 270, pp. 27-47.

[3] Zenzmaier, Ch.; Gesslbauer, B.; Grobuschek, N. Proteomic profiling of human stem cells derived from umbilical cord blood. Biochem. Biophys. Res. Commun., 2005, 328, 968-972.

[4] Righetti, P.G.; Castagna, A.; Antonucci, F. Proteome analysis in the clinical chemistry laboratory: myth or reality? Clin. Chim. Acta, 2005, 357, 123-139.

[5] Colantonio, D.A.; Chan, D.W. The clinical application of proteomics. Clin. Chim. Acta, 2005, 357, 151-158.

[6] Plebani, M. Proteomics: the next revolution in laboratory medicine. Clin. Chim. Acta, 2005, 357, 113-22.

[7] Patterson, S.D.; Aebersold, R.H. Proteomics: the first decade and beyond. Nat. Genet., 2003, 33, 311-323.

[8] Aldred, S.; Grant, M.M.; Griffiths, H.R. The use of proteomics for the assessment of clinical samples in research. Clin. Biochem. 2004, 37, 943-952

[9] Nakatogawa, H.; Ohsumi, Y. SDS-PAGE techniques to study ubiquitin-like conjugation systems in yeast autophagy. Methods Mol. Biol., 2012, 832, 519-529.

[10] Moroni, A.V.; Iametti, S.; Bonomi, F.; Arendt E.K.; Dal Bello F. Solubility of proteins from non-gluten cereals: A comparative study on combination of solubilising agents. Food Chem., 2010, 121, 1225-1230.

[11] Vallejo-Cordoba, B.; Rodriguez-Ramirez, R. Capillary electrophoresis for bovine and ostrich meat characterization. Food Chem., 2009, 120, 304-307.

[12] Schiffer, E.; Mischak, H.; Novak, J. High resolution proteome/ peptidome analysis of body fluids by capillary electrophoresi coupled with MS. Proteomics, 2006, 6, 5615-5627.

[13] Vallejo-Cordoba, B.; Vargas-Martinez, M.G. Capillary Electrophoresis Applications for Food Analysis. In: Handbook of Capillary and Microchip Electrophoresis and Associated Microtechniques; Landers, J.P.; Ed.; CRC Press: USA, 2008, pp. 853-912.

[14] Schwartz, H.E.; Palmieri, R.H.; Nolan, J.A.; Brown, R. Introduction to Capillary Electrophoresis of Proteins and Peptides; Beckman Coulter: California, USA, 1993.

[15] Zhu, Z.; Lu, J.J.; Liu, S. Protein separation by capillary gel electrophoresis: A review. Anal. Chim. Acta, 2012, 709, 21-31.

[16] Siquan, L.; Jianmin, F.; Ho-ming P. High-throughput protein analysis by multiplexed sodium dodecyl sulfate capillary gel electrophoresis with UV absorption detection. J. Chromatogr. A., 2004, 1051, 131-134.

This is an open access article licensed under the terms of the Creative Commons Attribution Non-Commercial License (http://creativecommons.org/licenses/ by-nc/3.0/) which permits unrestricted, non-commercial use, distribution and reproduction in any medium, provided the work is properly cited. 